\title{
APPLYING CASE-BASED REASONING IN THE EVOLUTION OF DEFORESTATION PATTERNS IN THE BRAZILIAN AMAZONIA
}

\author{
Joice Seleme Mota ${ }^{1}$, Gilberto Câmara ${ }^{1}$, Leila M.G. Fonseca ${ }^{1}$, Maria Isabel Sobral Escada ${ }^{1}$, \\ Olga Oliveira Bittencourt ${ }^{1}$ \\ ${ }^{1}$ Image Processing Division - National Institute for Space Research (INPE) \\ Avenida dos Astronautas 1758 - 12227-001 - São José dos Campos - SP - Brazil \\ ${ }^{1} 55$ (12) 3945-6000 \\ \{joice, gilberto, leila, isabel, olga\}@dpi.inpe.br
}

\begin{abstract}
Patterns of deforestation in Brazilian Amazonia are often associated with different actors, their economic activities and their land use and land cover change strategies. These patterns are often analyzed as static landscape objects, they are not treated as objects evolving along the time. This paper proposes to apply the CaseBased Reasoning (CBR) technique to establish rules and detect object deforestation evolution in an Amazonia region. The objects were analyzed in a sequence of images from different periods creating the base and rules to apply CBR. The application of CBR can help the specialist to understand how different landscape objects evolve, to establish object trajectories and to represent that evolution.
\end{abstract}

\section{Categories and Subject Descriptors}

I2 [Artificial Intelligence]: I.2.4 Knowledge Representation Formal e Methods - representations.

\section{Keywords}

Case-Based Reasoning, deforestation patterns, evolving objects.

\section{INTRODUCTION}

The use of natural resources in an indiscriminate way is causing negative effects all over the world to the ecosystems. Among the ecosystems disturbs or the human action destruction stands out the tropical forests, which shelter at least the half of the vegetable and animal species existent of the planet [21]. The tropical forests are important to stock carbon and provide habitats for several animal and vegetables species [7]. However, they are constantly under threat, mainly because of the dynamic use of the land [17]. The destruction of the tropical forests or its fragmentation are decisive processes so the species are extinguished (diversity loss) or if they turn more vulnerable to extinction [13]. After the fragmentation, the atmosphere is altered in its microclimate, environmental diversity, the community's dynamics, and diversity

Permission to make digital or hard copies of all or part of this work for personal or classroom use is granted without fee provided that copies are not made or distributed for profit or commercial advantage and that copies bear this notice and the full citation on the first page. To copy otherwise, or republish, to post on servers or to redistribute to lists, requires prior specific permission and/or a fee.

SAC'08, March 16-20, 2008, Fortaleza, Ceará, Brazil.

Copyright 2008 ACM 978-1-59593-753-7/08/0003...\$5.00. of species and in the original plenty of their population, which they can increase, decrease or destroy that place [14].

Recent research of deforestation evolution is important because of the need to know and control the risk areas. It would be more efficient if it was possible to suggest how could be the progress of deforestation in certain regions based on its initial pattern behavior.

A way to detect and to survey the change patterns in the biodiversity, provoked by human actions, is the use of remote sensing. The remote sensing is a useful tool to survey the covering of the tropical forest in the Earth surface because of the large volume and quality of images acquired everyday by a constellation of satellites [9]. The deforestation mapping and surveying, and the analysis of patterns in tropical forest could suggest political and local actions for the forest maintenance $[2,8,18,20,22,23,27]$. The monitoring of the forest and land use and land cover changes needs historical analyzes and they usually use satellite images or aerial pictures [17].

A series of succeeded studies exist, in trying of finding and defining deforestation patterns, using remote sensing tropical forests. Zipperer (1993) identifies five deforestation patterns (internal, identation, cropping, removal and fragmentation), in the state of Maryland, and it evaluates as the different patterns affect the forest through the analysis of land use change [26]. Casey and Caviglia (2000) propose the maintainable agriculture to try to minimize the deforestation in tropical forests. They trying to identify equalities in the form of land use for agriculture in Campeche, Mexico and in Rondônia, Brazil [4]. Linkie (2004) maps and analyzes forest loss in areas of the National Park of Kerinci in Sumatra with the goal of identifying more vulnerable areas to the deforestation. Spatiotemporal analysis in a sequence of images identifies the areas and taxes of deforestation for period. He tries to identify patterns through deforested areas near roads and rivers [19]. Chowdhury (2006) tries to quantify and to analyze the changes that occur in the landscape in Calakmul Biosphere Reserves in Mexico. The study evaluates biophysical variables, socioeconomic context and institutional causes that influence the deforestation in the area. The idea is to identify a behavior pattern that defines how the deforestation pattern is in the region [5].

In Amazonia, the main processes of land cover change are linked mainly to rural producers involved with agriculture, cattle ranching, mining and logging activities and their different 
strategies for land use [3]. The human occupation forms in areas of expansion of agricultural border are associated to different processes of land use and land cover changes. Escada (2003) defined a typology of land use and land cover patterns for the Center-north area of Rondônia in Amazonia [6]. This typology forms a synthesis of the main processes associated to the different categories of rural properties established in the region and the different occupation forms. Different actors involved in the change of the land use (small farmers, farmers, cattle breeders) can be distinguished by their different land use patterns [17]. These patterns evolve in time; new small settlements can emerge and large farms increase their agricultural area at the expense of the forest [24].

Silva (2005) treats the problem of detection of land use change patterns starting from the establishment of a land use and land cover typology and using methods for extraction of semantic information in satellite images and data mining techniques [24]. A structural classifier was used linking the specialist knowledge to patterns detected in the images [24]. One of the limitations of this approach is that the pattern is classified for a specific date representing a new object characterized as a new occupation. Using this approach once the object is classified it doesn't change anymore a significant part of the information of deforestation pattern such as its previous history, important to understand the evolution of land use change pattern is lost.

The goal of this paper is to extend the method proposed by Silva (2005) to identify cases and define how deforestation objects evolve in a rural settlement in Rondônia using of Case-Based Reasoning (CBR) technique. We presented a brief revision about CBR technique and its applications in section 2. In section 3 we showed the model of cases created. In the section 4 we presented CBR proposed under development. Section 5 presents the conclusion.

\section{CASE-BASED REASONING AND THEIR APPLICATIONS}

Case-Based Reasoning - CBR is a technique for problems resolution that recalls and adapts solutions used to solve similar previously problems $[1,16,28]$. CBR is based on the human natural reasoning and there are evidences that people use CBR in his daily reasoning.

The concept of CBR was developed, partly, as a reaction of some disadvantages of traditional techniques of artificial intelligence, as the Rule-Based Reasoning (RBR) that consists in analyzing a situation through a group of established rules.

One advantage of CBR about RBR is the knowledge getting. It is easier for specialists to explain new solutions previously recalling solutions for problems found than doing inferences potentially on a big group of rules. Systems based on rules do not have memory, forcing the construction of solutions starting from the beginning. When a problem does not fit in any rule, the system cannot simply solve it [15]. Systems based on cases, in other hand, possess memory of previous cases and continually increases allowing adapting cases with similar characteristics that can be useful to solve a new problem.

The basic cycle of processing CBR proposed by Aamondt and Plaza (1994) is composed by four main tasks: 1) to recover the most similar cases of the database cases, 2) to reuse the cases to solve the problem, 3) to revise the proposed solution and 4) to keep the experience representing the current case for future reuse [1].

CBR can be applied to the most varied domains. In that diversity, we can distinguish two basic types of CBR implementation: totally automatic system and recovery systems based on cases [16]. Automatic systems solve the problem in an autonomous way and have interaction mechanisms to evaluate the results of their decisions. Information recovery systems based on cases, make use of people to solve the problems, as an extension of the memory of the specialist who must use the reasoning and make the decision [15]. This work is developed based on this second implementation type.

Case-based reasoning presents characteristics that motivate its application in environmental modeling. Environmental problems are inherently complex and in general insufficiently known and modeled. CBR is a technique where the knowledge is modeled starting from samples, so it is not necessarily to model in a formal way the knowledge domain [15]. Kaster (2000) developed an application that has a mechanism of intelligent recovery and the edition of models uses techniques of Case-Based Reasoning. His goal is to aid users to develop new strategies of problems solutions of environmental planning. It starts from strategies already stored in a based on scientific workflows that interacts with a Geographic Information System (GIS) [15]. Another application that combines CBR and GIS is the system of classification of soils denominated ZONATION [11]. This system allows specialists to do classifications based in previous instances, using specific knowledge of the domain.

Other CBR approaches supporting applications related to environmental decisions have been developed. Hastings (1996) developed a system of alerts warning on infestations and grasshoppers combining $\mathrm{CBR}$ and reasoning based on models [10]. Verdenius and Broeze (1999) developed a system based on applied CBR to the domain of waters and sewer treatment using plants and microorganisms. The idea of the system consists in manage the level of oxygen and to decide in several situations which measure must be taken [25].

This paper combines CBR and the structural classifier aiming to identify evolution of deforestation patterns in Amazonia. We believe the deforestation evolution in settlements follows the same pattern. The CBR can present the history of the objects represented by deforestation object, allowing us to identifying when a different deforestation pattern occurs from the established pattern.

\section{DEFORESTATION EVOLUTION CASES}

The model of cases was generated from the analysis of deforestation evolution patterns in Agrarian Settlements Project called Vale do Anari in Rondônia. This settlement established by INCRA (Colonization and Land Reform National Institute), is located Vale do Anari municipality, in Rondônia state. This settlement project was established in 1982, with lots size of approximately 50 ha. The main process that was captured using the images mining was the concentration of lands lots [24]. This process can be described as a successive acquisition of land lots in a rural settlement drifted by the government, resulting in medium and big farms [6]. 
Aiming to detect spatial deforestation patterns dynamics and to associate them to different actors and processes three elementary structures were recognized in the analysis of deforestation data: irregular, linear and geometric [24]. Starting from the typology of land use and land cover patterns, the characteristics of those patterns, illustrated on Figure 1, were defined as:

Linear: distributed along roads as land use the hand of family work, subsistence agriculture and/or cattle breeding for small settlers.

Irregular: close spatial distribution to main roads and population nucleus, deforestation size less than 50ha, tends as land use the hand of family work, subsistence agriculture and/or cattle breeding for small settlers.

Geometric: large deforestation than 50ha, tends as land use of the cattle breeding for medium and big farmers.

Those patterns were classified in Vale do Anari in the period from 1985 to 2000 capturing the areas of land concentration that differ from the typical pattern of settlements projects.

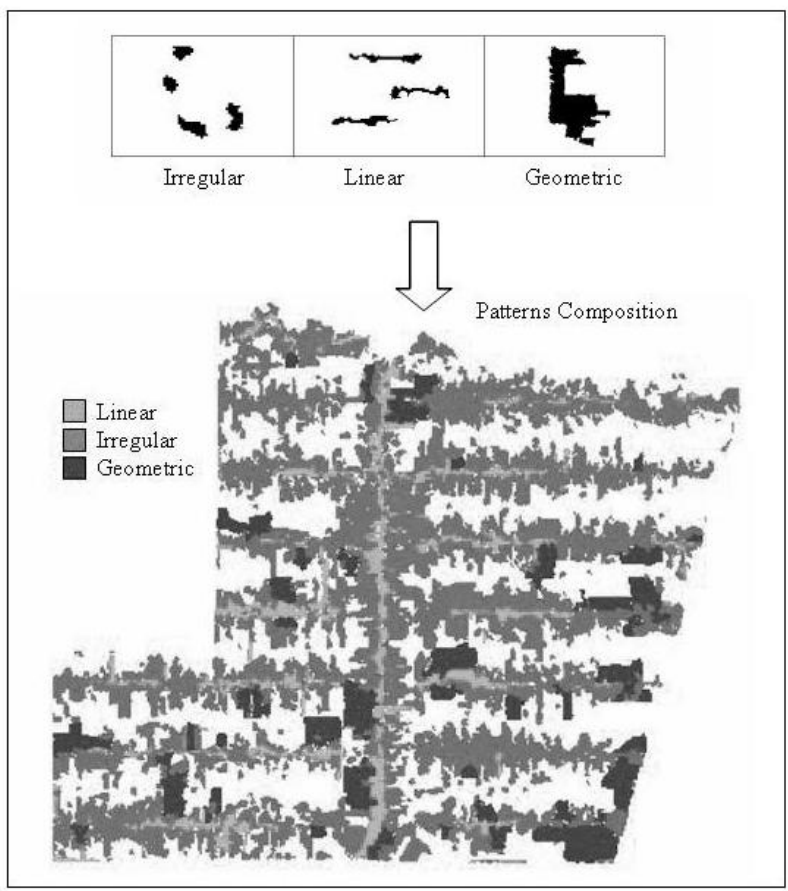

Figure 1. Deforestation Patterns of Vale do Anari Source: Silva (2005)

We propose the description of deforestation pattern evolution in the study area, presenting the history of the objects representing deforestation and allowing us to identify cases defining how the patterns are formed.

The deforestation evolution was evaluated in a temporal images series TM/Landsat 5 (231/66 and 231/67, from 1985 to 2000, with resolution of $30 \mathrm{~m}$ ) [12], classified by the structural classifier. We studied the spatial relationship (touch, inside) among the objects that represent the patterns in different periods of time. The goal was to show the cases where two areas deforested in different periods represent the same area and they should be united, and when they should be maintained in separate suggesting not in concentration. Table 1 presents the illustration of the group of studied patterns.

Table 1. Objects evolution representing the deforestation patterns.

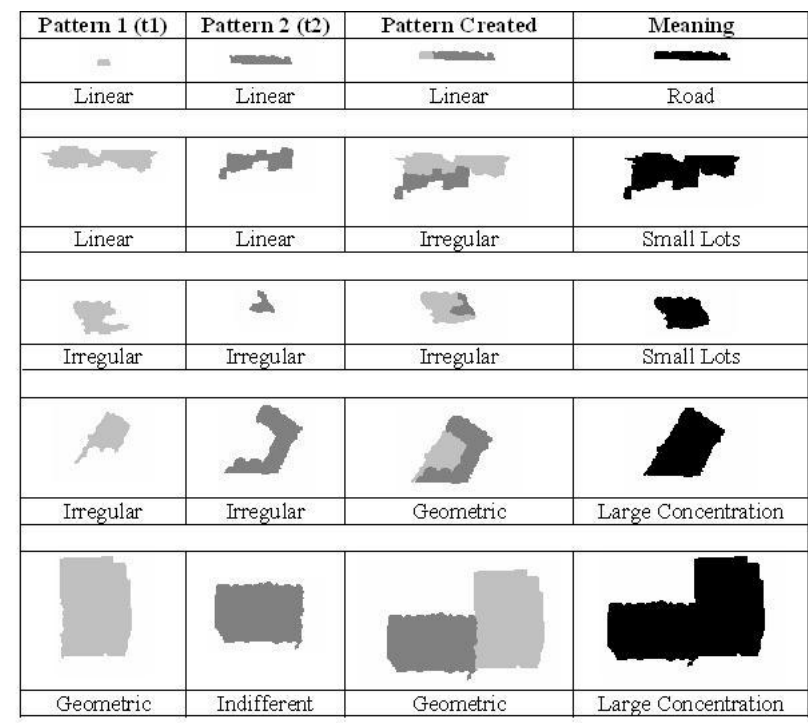

We noticed that depending on the context the union represents the deforestation evolution of object however in certain cases the union of two objects should not be done, because it doesn't represent its evolution, but two different objects. Another situation is that in settlements projects the lots are distributed along the roads and the deforestation of a lot begins starting from the roads for the bottoms of the lot. Deforestations along the roads belong to different lots, in other words, they are different objects. In that way it is fundamental for CBR to know the object with typology road is defined in the first period of evaluation. The Figure 2 shows the need to increase the context in the study of objects evolution.

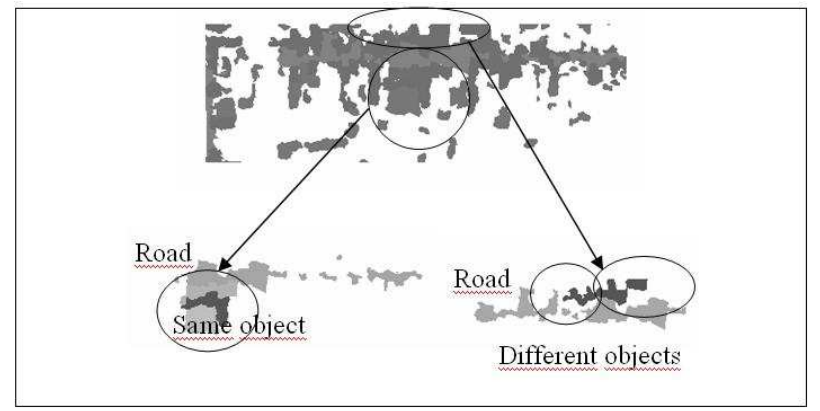

Figure 2. Study of the context in the evolution of the objects.

Table 2 presents the first cases created to exemplify that study and to compose the database cases of CBR proposed. 
Table 2. Cases created starting from the studies of the deforestation evolution.

\begin{tabular}{|l|c|c|c|c|c|c|c|}
\hline Cases & \multicolumn{9}{|c|}{ Problems/Symptoms } & \multicolumn{2}{c|}{ Solution } \\
\hline & Problem & Pattern 1 & Pattern 2 & $\begin{array}{c}\text { Pattern } \\
\text { Created }\end{array}$ & Context & Diagnosis & Operation \\
\hline Case 1 & $\begin{array}{c}\text { To define } \\
\text { evolution }\end{array}$ & Linear & Linear & Linear & Indifferent & Road & Union \\
\hline Case 2 & $\begin{array}{c}\text { To define } \\
\text { evolution }\end{array}$ & Linear & Linear & Irregular & Indifferent & Small lots & Union \\
\hline Case 3 & $\begin{array}{c}\text { To define } \\
\text { evolution }\end{array}$ & Irregular & Irregular & Irregular & $\begin{array}{c}\text { Vertical the } \\
\text { road }\end{array}$ & Small lots & Union \\
\hline Case 4 & $\begin{array}{l}\text { To define } \\
\text { evolution }\end{array}$ & Irregular & Irregular & Irregular & $\begin{array}{c}\text { Along the } \\
\text { road }\end{array}$ & $\begin{array}{c}\text { Small } \\
\text { different }\end{array}$ & Separate \\
\hline Case 5 & $\begin{array}{c}\text { To define } \\
\text { evolution }\end{array}$ & Irregular & Irregular & Geometric & $\begin{array}{c}\text { Indifferent } \\
\text { Large } \\
\text { concentration }\end{array}$ & Union \\
\hline Case 6 & $\begin{array}{c}\text { To define } \\
\text { evolution }\end{array}$ & Geometric & Indifferent & Geometric & Indifferent & $\begin{array}{c}\text { Large } \\
\text { concentration }\end{array}$ & Union \\
\hline
\end{tabular}

These cases consider the analysis done about classification of the patterns, the union in different periods and the result of that union. It also considers the spatial distribution of the objects about road to define two objects that touch each other, they should be united or kept in separate.

\section{CBR FOR EVOLUTION OF DEFORESTATION PATTERNS}

CBR here proposed will interact with the images database created by the structural classifier. The objects of those images classified in patterns are not directly the entry data for CBR. Those data should be used to create the new case agree with the established attributes (pattern 1, pattern 2, created pattern, and context). With the new created case, CBR looks for the most similar case [28] in cases database to aid the specialist in the socket of decision for representation of the objects evolution (Figure 3 ).

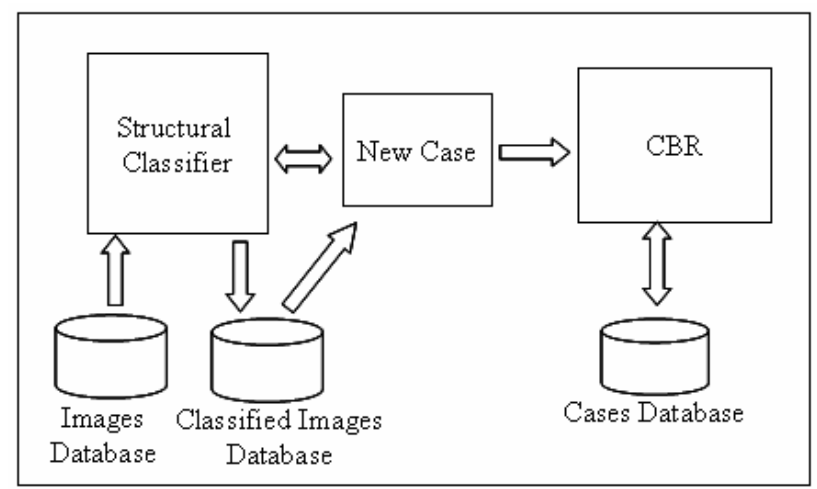

Figure 3. CBR for evolution of deforestation patterns.

The new case needs to be created because the structural classifier classifies the patterns statically. The module that is called new case has as objective to look for patterns classified in a series of images, to unite the objects that possess spatial relationship and to classify that new created object (Figure 4). On this moment three of the four attributes of the problem of the model of cases are created (pattern 1, pattern 2 and created pattern). The context must be defined by the specialist's intervention that will define what objects are, for instance, along the roads or vertical the road. The default context is indifferent. The new created case is the entry of CBR that looks for the most similar case in the base of cases (recovery), that it can be used in the solution of the problem (reuse) or adapted if it is necessary (revision), and stored for future use (retention).

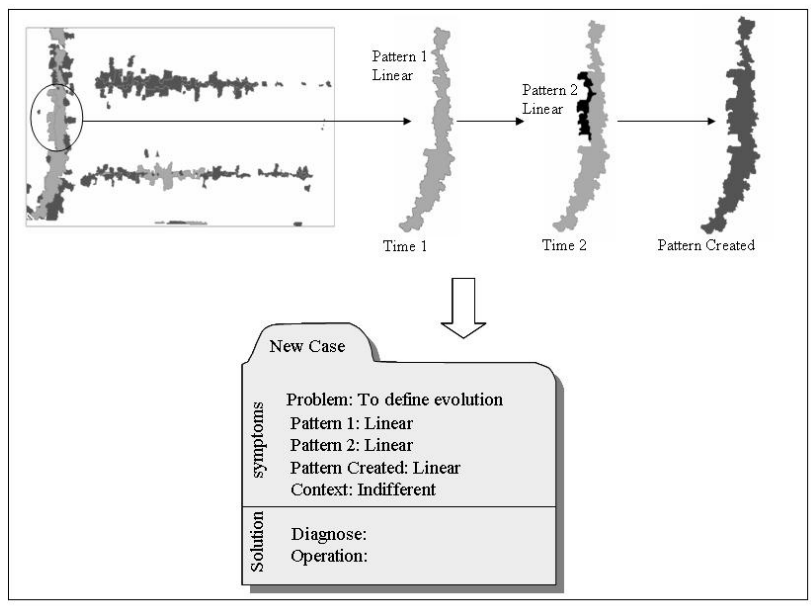

Figure 4. New case created.

The solution proposed by CBR, allied to the specialist's knowledge, defines the operations will be used (to unite or to maintain).

\section{CONCLUSIONS}

This paper proposes a CBR, still in development, to aid the specialist to analyze deforestation patterns evolution in Brazilian Amazonia. CBR will interact with an already existent structural classifier that classifies deforestation patterns agree with a land use and land cover established typology. Starting from the classified images the new case is created (problem) and the database cases is researched in search of cases previous with similar description the current situation. The group of first cases created needs to be improved, and despite of the base to be updated with new cases, studies continue to be accomplished for the search of the best representation of the reality. The cases can be exported so their rules are applied in new systems with the goal of preserving and to present the history of evolving objects. We suggested applying CBR in different agrarian settlements projects to validate the cases.

\section{REFERENCES}

[1] Aamodt, A.; Plaza, E. Case-based reasoning: foundational issues, methodological variations and system approaches. AI Communications, 7(1):39-59, 1994.

[2] Armenteras, D.; Rudas, G.; Rodriguez, N.; Sua, S.; Romero, M. Patterns and causes of deforestation in the Colombian Amazon. Ecological Indicators, v. 6, n. 2, p. 353$368,2006$.

[3] Becker, B. K. Amazônia. São Paulo: Ática, 1997. 112 p.

[4] Casey, J.F.;Caviglia, J.L. Deforestation and Agroforestry Adoption in Tropical Forests: Can We Generalize? Western Agricultural Economics Association Annual Meetings, Vancouver, British Columbia, 29-July 1, 2000.

[5] Chowdhury, R.R. Landscape change in the Calakmul Biosphere Reserve, Mexico: Modeling the driving forces of smallholder deforestation in land parcels. Applied Geography. Volume 26, Issue 2, April 2006, Pages 129-152. 
[6] Escada, M. I. S. Evolução de Padrões da Terra na Região Centro-Norte de Rondônia. Tese de Doutorado em Sensoriamento Remoto. Instituto Nacional de Pesquisas Espaciais, São José dos Campos, 2003. 164 p.

[7] Fearnside, P. M. Deforestation in Brazilian Amazonia: history, rates, and consequences. Conservation Biology, v. 19, n. 3, p. 680-688, 2005.

[8] Ferraz, S. F. B.; Vettorazzi, C. A.; Theobald, D. M.; Ballester, M. V. R. Landscape dynamics of Amazonian deforestation between 1984 and 2002 in central Rondônia, Brazil: assessment and future scenarios. Forest Ecology and Management, v. 204, p. 67-83, 2005.

[9] Freitas, S. R.; Shimabukuro, Y.E. Diagnosticando Florestas Tropicais através do sensoriamento remoto. In: Simposio Brasileiro de Sensoriamento Remoto, 13. (SBSR), 2007, Florianópolis. Anais. São José dos Campos: INPE, 2007, p. 6453-6460.

[10] Hastings, J.D. A Mixed Paradigm Approach to Problem Solving in Incomplete Causal-Theory Domain. PhD thesis, University of Wyoming, Laramie, Wyoming, 1996.

[11] Holt, A.; Benwell, G.L. Applying case-based reasoning techniques in GIS. The International Journal of Geographical Information Science, 13(1):9-25, 1999.

[12] INPE. Monitoramento da Floresta Amazônica Brasileira por Satélite - Projeto PRODES 2003. Disponível em: http://www.obt.inpe.br/prodes/. Accesso em: set/2007.

[13] Kageyama, P. and Lepsch-Cunha, N. M. 2001. Singularidade da biodiversidade nos trópicos. In: GARAY, I. \& DIAS, B. Conservação da biodiversidade nos trópicos. Petrópolis, Vozes. p.199-214.

[14] Kapos, V. 1989. Effects of isolation on the water status of forest patches in the Brazilian Amazon. Journal of Tropical Ecology 5(2): 173-185.

[15] Kaster, D. S.; Medeiros, C. B.; Rocha, H. V.. Aplicação de raciocínio baseado em casos a sistemas de apoio à decisão ambiental. In: II Workshop Brasileiro de Geoinformática, 2000, São Paulo. Anais II GeoInfo'00, 2000.

[16] Kolodner, J.L.; Jona, M. Y.. Case-based reasoning: An overview. Technical Report 15, Northwestern University, June 1991.
[17] Lambin, E. F.; Geist, H. J.; Lepers, E. Dynamics of land-use and land-cover change in tropical regions. Аnnu. Rev. Environ. Resour., v. 28, p. 205-241, 2003.

[18] Laurance, W. F.; Albernaz, A. K. M.; Schroth, G.; Fearnside, P. M.; Bergen, S.; Venticinque, E. M.; Costa, C. Predictors of deforestation in the Brazilian Amazon. Journal of Biogeography, v. 29, p. 737-748, 2002.

[19] Linkie, M.; Smith, R.J. and Leader-Williams, N. Mapping and predicting deforestation patterns in the lowlands of Sumatra. Biodiversity and Conservation 13, 1809-1818, 2004.

[20] Mendoza, J. E.; Etter, A. Multitemporal analysis (19401996) of land cover changes in the southwestern Bogotá highplain (Colombia). Landscape and Urban Planning, v. 59, p. 147-158, 2002.

[21] Myers, N. 1997. Florestas tropicais e suas espécies sumindo, sumindo. . . ? In: Wilson, E. O. Biodiversidade. Rio de Janeiro, Nova Fronteira. p.89-97.

[22] Pfaff, A. S. P.; Sanchez-Azofeifa, G. A. Deforestation pressure and biological reserve planning: a conceptual approach and an illustrative application for Costa Rica. Resource and Energy Economics, v. 26, p. 237-254, 2004.

[23] Perz, S. G.; Aramburú, C.; Bremner, J. Population, land use and deforestation in the Pan Amazon basin: a comparison of Brazil, Bolivia, Colombia, Ecuador, Perú and Venezuela. Environment, Development and Sustainability, v. 7, p. 2349, 2005.

[24] Silva, M. P. S.; Câmara, G.; Souza, R. C. M.; Valeriano, D. M.; Escada, M. I. S. Mining Patterns of Change in Remote Sensing Image Databases. INPE, São José dos Campos, 2005.

[25] Verdenius, V.; Broeze, J. Generalized and instance especific modelling for biological systems. Environmental Modelling and Software, 14:339-348, 1999.

[26] Zipperer, W.C. Deforestation patterns and their effects on forest patches.Landscape Ecology 8:177-184, 1993.

[27] Walker, R. Theorizing land-cover and land-use change: the case of tropical deforestation. International Regional Science Review, v. 27, n. 3, p. 247-270, 2004.

[28] Wangenheim, C.G and Wangenheim, A. Raciocínio Baseado em Casos. Barueri, SãoPaulo: Manole, 2003. 